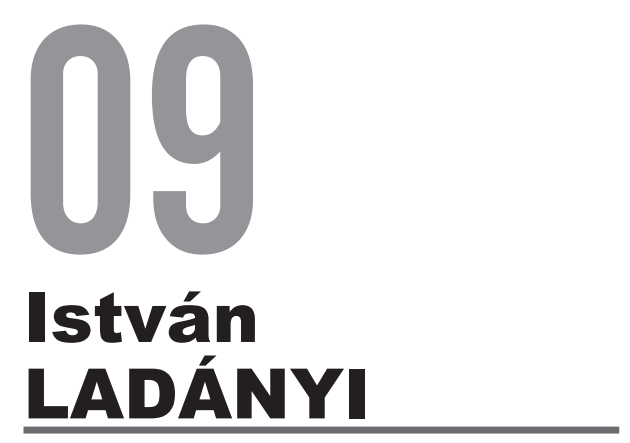

Veszprém

Izvorni znanstveni rad

\title{
Događaj i naracija u Sentimentalnom putovanju Ferenca Fejtöa
}

$\mathrm{P}$ ozivajući se naslovom svoje knjige na Sentimentalno putovanje Laurencea Sternea, Ferenc Fejtö skreće pozornost i na hijat koji postoji između zbivanja, čina putovanja, njihove percepcije, okolnosti svedenih na činjenice, kao i načina na koji se sve to pripovijeda. Naslovom se poziva na jedno prethodno, poznato i ugledno djelo čime skreće pozornost na samu djelatnost opisivanja putovanja, referirajući se na raznolikost putovanja i tradiciju putopisanja. Odnos između događaja i pripovijedanja povezan je i s problemom žanrovske određenosti Fejtöva djela.

Ova se knjiga u pogledu prakse pisanja romana u 20. i 21. stoljeću bez problema može čitati kao roman. Mnogo je elemenata u njoj na temelju kojih bismo je mogli svrstati i pod autobiografiju, i pod putopis, ali i pod esej. Međutim, osobita karakteristika djela je da stalno zahtijeva nefikcionalno čitanje, da ga, bez obzira koliko je nepoznato i neprovjerljivo za nas ono o čemu priča, na temelju provjerljivih relacija i u svjetlu tradicije iščitavanja tekstova, ipak čitamo kao djelo koje govori o zbilji i nastoji da bude istinito. Pretpostavljamo stvarne događaje koji su prethodili tekstu, povezujemo ga dakle sa stvarnim putovanjem Ferenca Fejtöa, a prema tim događajima pripovjedač se odnosi jedinstveno, ali s pretenzijom za izricanjem istine.

Sentimentalno putovanje jedinstveno je djelo u autorovu opusu. Također autobiografski tekst Od Budimpešte do Pariza preko Zagreba više odgovara 
tradicionalnom žanru memoara u kojemu pokušava istodobno ispričati i pojedinosti i cjelinu jednog proživljenog života, cijelom proživljenom životu podiže spomenik i pridaje važnost, uzimajući u obzir povezanost vlastitog života u cijelosti. Sentimentalno putovanje pripovijedanje je jednog - točnije dvaju skupa doživljaja. Za mladog Mađara dani provedeni sa zagrebačkom granom obitelji, kao i doživljaj putovanja po hrvatskom Jadranu pretvaraju se u događaje koji se nameću da budu ispripovijedani. Po uzoru na romane o putovanjima izvješće je to o putovanju koje iskustveno ja pretvara u pripovjedača. $\mathrm{Na}$ taj način doživljaji stečeni na putovanju potiču na suočavanje sa samim sobom, tijekom čega iskustveno ja u zrcalu proživljenog preispituje samog sebe, istovremeno kao samog sebe i sebe kao stranca.

S jedne strane putuje u poznati svijet - na mjesto svog djetinjstva i u krug vlastite obitelji - ali taj svijet, promjenama zahvaćena okolina koja ga dočekuje i iskustveno ja, odrastao mladić koji se nakon dugo vremena vraća u Zagreb već su se toliko udaljili da se jedno prema drugome odnose onkraj samorazumljivosti potičući iskustveno ja na neprekidno vaganje, ispitivanje i tumačenje. Roman započinje graničnom situacijom, a proživljeni događaji do kraja priče zadržavaju karakter graničnih događaja. Prva rečenica prepričava prijelaz granice u strogom smislu te riječi, no u priči se pretvara u prijelaz granice i u simboličnom smislu. Povijest država, rata i granica, kao i povijest obitelji unutar te velike povijesti stavljaju na kušnju identitet iskustvenog ja, susreti ga potiču na ponovno tkanje obiteljske mreže, prisiljavaju na tumačenje odnosa i veza. Putovanje u Zagreb postaje put suočavanja s majčinim nasljedstvom, dok pripovijedanje znači prihvaćanje vlastitoga života onakvim kakav jest, njegovo prisvajanje koje se ostvaruje kroz pripovijedanje. S tim u vezi možemo aktivirati pojam granične situacije Karla Jaspersa: „...To znači da su to situacije, povrh kojih ne možemo ići, koje ne možemo mijenjati. Čuđenje i sumnja: prepoznavanje je tih graničnih situacija."1

S druge strane, nakon Zagreba putuje u jedan potpuno drugačiji svijet, nadograđujući se na prisnu tuđinu dana provedenih u Zagrebu, more, primorski način života, onodobni već funkcionalni turizam te susreti s drugim putnicima mladića, koji putuje sam, neprestano potiču na razmišljanje i samorefleksiju. I ovdje je naglašeno izražen prelazak granice: opažanje mora i kod Fejtöa će, kao i kod mnogih drugih putnika s kontinenta, biti vrlo značajan graničan događaj - u priči suprotstavljen neosjetljivim, nesklonim putnicima koji istu tu okolnost ne doživljavaju kao događaj.

Wolf Schmid u djelu Elemente der Narratologie događaj definira kao promjenu stanja koja prolazi kroz „specifične uvjete i tako dobiva značaj”2. Jurij

1 Karl Jaspers, Uvod u filozofiju, Dvanaest radijskih predavanja, s njemačkog preveo Željko Pavić (Zagreb: Naklada Breza, 2012), 16.

2 Wolf Schmid, Elemente der Narratologie: 3, etweiterte und überarbeitete Auflage (Berlin: De Gruyter, 2014), 14-15. 
Lotman pojam dovodi u vezu s prekoračivanjem unaprijed postavljenih pravila, primjerice s „kršenjem kakve zabrane”. ${ }^{3}$ Árpád Kovács, jedan od Lotmanovih mađarskih tumača, pomno proučavajući pojam događaja važnim razlikovanjem smatra odvojiti događaj od domene neposrednog iskustva: „Konvencionalan pristup događaj poima uspoređujući ga sa stanjem, procesom, promjenom i pretvorbom. Međutim, moramo znati da ovaj pristup ne pretače u formu izravno iskustvo. Naše prethodno shvaćanje temelji se na pretpostavkama, reprezentacijama, simboličnim posredovanjima." ${ }^{4}$

U svijetu djelovanja i zbivanja formiranje događajnosti u sebi već a priori sadrži smještanje u odnose koji daju smisao, pridaju značenja i važnost. Jedna radnja, zbivanje poprima značaj koji nadilazi njihove okvire. „Prema većini naratoloških teorija događajem se može smatrati ono što uslijed narativnog posredovanja postaje komponenta jedne priče: pripovijedanje integrira događaj u priču."

U interpretacijama vlastita života, u samointerpretacijama stalno prisutnim u svijetu radnji, ili u žanrovski različitim, pismenim ili usmenim inačicama samopričanja pojedina radnja, zbivanje ističe se dakle iz beskrajnog niza radnji i zbivanja, zadobiva status događaja, postaje dijelom procesa shvaćanja i samoshvaćanja zajedno s njemu pripisanim/u njemu prepoznatim značenjima.

Događaj, dakle, nije sve ono što se zbiva, već ono što se ispunjeno značenjima iz svijeta radnji i zbivanja iscrtava za ja koje ih proživljava i pripisuje sebi. I sam je stvorena, kognitivna konstrukcija. Za to je potrebna pozornost iskustvenog ja, kao i njegovo razlučivanje i pridavanje smisla. U njemu dolaze do izražaja svi oni ranije stvoreni kulturni sklopovi koje iskustveno ja nosi, prethodna uobličavanja koja iskustveno ja ovjerava u svom djelovanju, kao i koreografija radnji i aktivnost tumačenja ostalih sudionika.

Osim referenci na Sterneovo Sentimentalno putovanje Fejtö na brojnim mjestima jasno ukazuje na književnu uobličenost pripovijedanja, prisutnost književnih predložaka, kao i na iskustvo posredovano, a istovremeno i oblikovano kroz pripovijedanje.

Uz glas pripovjedača, Fejtö u sebi svojstvenoj polifoniji dosljedno daje glas likovima uvedenima kroz pripovijedanja, likovima pomoću kojih se iskustveno ja suočava s determiniranostima koje je na njega prenijela obitelj, likovima čija naracija (i djelovanje) oblikuje iskustveno ja koje promatra sebe; a u pripovijedanju ta naracija i djelovanje pak oblikuju pripovjedačko ja.

Autonarator u brojnim prilikama prepušta riječ jednom od likova ili u neupravnom govoru prenosi njihove riječi. Štoviše, poigrava se i suprotnom meto-

${ }^{3}$ Citira Schmid, Elemente der Narratologie, 13.

4 Árpád Kovács, Az irodalmi esemény, (Budapest: Gondolat, 2013), 11. [Universitas Pannonica Könyvek 22]

5 Kovács, $A z$ irodalmi esemény, 14. 
dom: pripovjedač koji promatra sebe počinje pripovijedati o sebi u trećem licu, čineći tako formu pripovijedanja reflektivnom.

Karakterističan primjer prvog slučaja pripovijedanje je njegove sestre Nade u prvom licu. U kompoziciji sličnoj dnevniku u dijelu zabilježenom pod datumom drugi srpnja, nakon kraćeg uvoda u kojemu se predočuje situacija („Nada se odmara na krevetu i proučava pomake čeda u sebi, nagađajući hoće li biti dečko ili curica.") odnosno nakon iskaza vezanog uz budućnost sestra počinje pričati vlastitu priču. Referirajući se na autorovu aktivnost pisanja dnevnika, daje mu savjete i objašnjava kako da je opiše u dnevniku. ${ }^{6}$

"- Voljela bih znati što to stalno bilježiš i zašto ne želiš pokazati? Po svemu sudeći i ti pišeš memoare, kao što je to u posljednje doba postalo navadom pisaca. No otkako si postao velik dečko, sa mnom još nisi ni razgovarao pa stoga ni ne znam što bi uopće i mogao pisati o meni? A bila bih pogođena ako me ne bi bilo u tvojim memoarima. Ipak, ukoliko me spomeneš, zahtijevam od tebe da ne pišeš o mojoj malograđanštini već da stvari malo idealiziraš. Ja sam sada filistarka s golemim trbuhom, polako šijem odjelca za svoje dijete te osim kućanstva nemam nikakve druge brige. Ne stignem baš ni čitati knjige i posve sam zaostala u odnosu na svijet oko mene, polako zaboravljam čak i mađarski, a izgubila sam i zanimanje za probleme višega reda."7 Njegova sestra dakle traži da bude uvedena u priču i nudi već ranije formiranu sliku sebe, krečući se zapravo između željene slike same sebe naslijeđene iz prošlosti i one slike kakvom se danas vidi. Nakon svega toga slijedi sažetak same priče koji se proteže preko brojnih stranica. Na kraju poglavlja upadljiva je Fejtöva autorska odluka da riječ ne prepusti opet pripovjedaču, dakle sestrino pripovijedanje ne dobiva okvir. Istovremeno s gestom tako predane riječi nagoviješta da pripovjedač ne preuzima Nadinu sliku o samoj sebi, ne interpretira je u vlastitu sliku, već je u svojoj priči ostavlja kao strani glas koji vodi dijalog s vlastitim glasom.

Slično tome, u različitim verzijama priča, u narativnoj strukturi rodbinskih posjeta ocrtava obiteljsku galeriju portreta - s vremena na vrijeme, pripovjedačkim sredstvom usklađenim pripovijedanoj osobi ukazuje na uvjetovanost interpretacija, podrazumijevajući pod tim kako samotumačenje junaka tako i tumačenje pripovjedača. Ironija i autoironija, osviještene kratke pripovjedne forme ili druga sredstva pripovjedačkog uokvirivanja čine vidljivom aktivnost pripovjedača.

Fejtöv pripovjedač do samog je kraja svjestan svog književnog postupka, prepoznaje, zapisuje i tumači ne samo svoju spisateljsku djelatnost, nego i igru u svijetu događaja, aktivno stvorene koreografije, sljedove događaja

6 Ferenc Fejtö, Sentimentalno putovanje, (Zagreb: Durieux, Dubrovnik: Dubrovnik University PreSS, 2003), 49.

7 Fejtö, Sentimentalno putovanje, 50. 
ostvarene prema poznatim uzorcima. Lik ujaka Otta (koji se u prvom izdanju, u Zagrebačkom dnevniku s putovanja još pojavljuje kao ujak Józsi) ${ }^{8}$ prikazuje nam se kao pomalo komičan lik iz starih filmova koji su nastajali kroz brzu izmjenu pokretnih slika, s do kraja pravilno odrađenom koreografijom samoborskog izleta. Glumica Erika Druzović u djelu igra iznijansirano izrađen prizor, i u tom slučaju Fejtö ironiju ostvaruje ne samo u postavljanju lika na scenu, već i u samom pripovjedačkom pojednostavljivanju.

„Sve je od toga u sobi postala uloga, igra, napetost i drama. Govorila je hitro, čas ovome, čas onome, razbacivala je te svoje tri uloge poput žonglera koji baca i hvata tri tanjura u isti čas; komunicirala je bez trenutka stanke trima glasovima s crescendima i accelerandima; čudesno. Živjela je na tri razine istodobno, otprilike tako da je nešto rekla teti Toni, pritom jela s tanjura ujaka Otta, a mene gledala u oči ili obrnuto: vragoljasto se smješkala prema ujaku Ottu, milovala ruku tete Toni, a mene pitala duboko sućutno: ah, vi ste književnik? Možda pišete romane? Onda napišite i roman o meni. Hoćete, zar ne?" ${ }^{\prime \prime}$ A majčin odavno umrli lik koji stoji iza cijelog tog zagrebačkog puta formira se kroz rukopise koje ujak Otto predaje već odraslom mladiću: kroz napisana i primljena majčina pisma i ostale dokumente. Mladić sada u ruci drži listove papira svojedobno napisane majčinom rukom, opipava ih, čita rukopis i zapisuje ono što čita na tim papirima. Na ovo neposredno iskustvo priprema ga poglavlje sadržajno suprotnog predznaka koje mu u strukturi knjige gotovo prethodi: kratki - i u priči također jako kratko opisan - posjet majčinom grobu, gdje se još ne odvija susret s majkom, pripovjedač opisuje prazninu i majčinu udaljenost.

Mladić cijelu večer provodi čitajući pisma koja, bogata detaljima, prizivaju majku i nekadašnji život.

„Koliko li se tu novih crta lica javlja, lica koje se blijedo, valjda samo po fotografiji sjećam! Gotovo osjećam njezin dah iznad lista papira na koji je crtajući nizala svoja prekrasna slova! Vidim joj večernji sjaj u očima kada se naginjala kroz prozor riječkoga stana iznad živopisne i bučne ulične vreve, vidim je u šetnji pod palmama perivoja uz Guvernerovu palaču dok maše svojom lepezom od žućkaste kosti i hladi lice ili tjera od sebe komarce, a iz paviljona se čuje glazba! (...) Vidim svoju majku onakvu kakvu sam ju želio vidjeti na groblju, kako me gleda tužno i ljubazno, mrtvo ali ipak i živo s nekoga prostora koji nije izvanjski već unutarnji, a gleda me onako kako znaju katkada gledati i jedva se primjetno pomaknuti slike iz pozlaćenog okvira."10 I drugi dan provodi u čitanju pisama, u dnevničkoj strukturi romana i taj je dan u potpunosti posvećen

\footnotetext{
8 Vidi: Fejtő Ferenc, „Zágrábi utinapló”, Nyugat, 1935, 11. Pristup: 10. listopada 2018. http://epa. oszk.hu/00000/00022/00598/18907.htm

9 Fejtö, Sentimentalno putovanje, 67.

${ }^{10}$ Fejtö, Sentimentalno putovnje, 102-103.
} 
liku majke uz prepričavanje i interpretaciju dijelova pisama. Mjestimice nagoviješta majčinu pristranost koja u pismima posreduje i tumači događaje iz svoga života, potom u priču upliće i obiteljsku interpretativnu mrežu, poimence imenujući unaprijed formirano značenje glasina, zatim glasom tete Dore nazivajući majčinog prvog supruga Karenjinom, daje nagovijestiti koliko su se u tumačenje osoba i događaja uplele pročitane knjige, gotovi interpretacijski obrasci, likovi u samointerpretaciji, ali možda i u svojim djelovanjima kao da prisiljavaju jedni druge i same sebe na uloge koje su im poznate iz književnih djela. Rijeka prizvana putem majčinog lika već nas uvodi u drugi, jadranski dio knjige. Fejtö pohvalu Rijeci, u vokativu sukladno žanru pohvalnica gradu, stavlja na kraj niza poglavlja koja govore o majci. „Slava i tebi Rijeko (Fiume) kao i tvojemu melodioznome, mekanom imenu koje je ugodno poput žubora potoka Rječine (Fiumara) uz tvoju granicu! Slavim tebe, plavetnilo tvojega Kvarnera i tvoja bijela jedra koja lebde između neba i vode!"11 Ta je pohvala parnjak pohvali Zagrebu, na to ukazuje „i” s početka rečenice. „Slava i tebi Rijeko..." Pohvala Zagrebu slijedi neposredno nakon dolaska u grad, kada putnik prvi puta izlazi u šetnju gradom i odlazi sa sestrom na tržnicu. Na svjesnu formiranost romana (nasuprot dnevničkom, spontanom prenošenju putovanja) upućuju i ta dva međusobno daleka vokativa, naime, obraćajući mu se, i Zagreb hvali i smatra svojim: "Zagrebe, ti si moj rodni grad; premda se u tebi nisam rodio, u tvojem se krilu ipak osjećam posve kod kuće." ${ }^{12}$ Sukladno žanru pohvalnice gradu i ovdje navodi dragocjenosti grada, a suprotno tom istom žanru pored poistovjećivanja, uvodi i osobno distanciranje.

No prije Rijeke, pri kraju dijela o Zagrebu, nalazi se još i susret s Krležom, kao i rođenje nećaka, Nadinog sina. Nećakovo rođenje zatvara niz zagrebačkih događaja, okrećući sada obiteljsku povijest prema budućnosti.

Put po obali, uz more koji započinje u vlaku prema Rijeci, slijedi tradicionalnu naraciju putopisa, obilaske mjesta te opise susreta sa suputnicima. U Fejtövom prisjećanju puta po Jadranu prepoznajemo jedan markantan pripovjedački obrat koji možemo smjestiti uz pohvale Zagrebu i Rijeci. Pri kraju putovanja po obali, pripovjedač koji neprestano promatra sebe i zapisuje događaje, jednom zapravo ironičnom gestom skida koprenu s pozicije samopromatrača i pripovjedača, te pripovijedanje prebacuje u drugo, a potom u treće lice. Promjena se događa u okviru književne tradicije i kontekstualizacije domene uloge pisca.

„Prijepodne sam nakon dugoga traganja uspio pronaći Hellino ime u knjizi gostiju jednoga pansiona. Prezime sam joj zaboravio i tek sad sam ga se sada sjetio: Čehova. Moram se sjetiti Čehovljeva Galeba i one tupe strasti koja u

\footnotetext{
${ }^{11}$ Fejtö, Sentimentalno putovnje, 134.

12 Fejtö, Sentimentalno putovnje, 26.
} 
očima čehovljevskoga pisca svaki životni postupak, svaki intimni trzaj duše preobrazuje u »temu«, u slovo, u bilješku. A sada i ja sjedim ovdje i bilježim u nekakvu začudnom pomaku od samoga sebe. (...) Sjećam se još iz doba puberteta kakva mi je čudnovata bila spoznaja toga šestog osjetila, kako me je zbunjivalo i šalilo se sa mnom, kako mi se zgadilo da će bilo što mislim ili učinim, bilo da me boli, sve to »šesto osjetilo« primijetiti i bilježiti, od svega nastojati proizvesti rečenicu, ravnodušno, bez sućuti, podrugljivo. Ono zbog čega se toga stanja najviše gnušam njegova je mehaničnost. Zaljubiš se i smjesta osluškuješ u sebi to trabunjanje »o-sje-ća za-lju-blje-nost«. Gotovo u trećem, dapače, čak u petom licu. »Kosa joj je takva, a vrat onakav itd." Nešto tu ne valja! »Osjeća, hm, da tu nešto ne valja«, a najenervantnije je to što se ti mašeš olovke i zapisuješ ono što ti diktira."13 Ovdje pripovjedač pripovijeda već u drugom licu, oslovljava piščevo Ja, a treće i peto lice je onaj koji diktira. Promatranje strukture vlastitog života postaje poput čitanja romana. „Prvo lice postaje suvišnim”, kaže Fejtöv pripovjedač: „Zapisuješ: Hellu nije našao kod kuće, jer je na barci otišla na ribarski izlet i nije izvjesno kada će se vratiti." ${ }^{4}$ I dalje bi se mogli nizati primjeri tog autorefleksivnog umetanja spisateljske djelatnosti u priču, koje se zatvara predočavanjem i komentiranjem same autorefleksije. Taj dio teksta smješta se na istaknutom dijelu knjige, na samom kraju, komentirajući cjelokupnu djelatnost pripovjedača. Iza toga nalazi se samo događaj početka povratka, ulazak u vlak iz Splita za Zagreb. Ovdje pripovjedač zašuti, od Zagreba se već oprostio prije putovanja u Rijeku, ispripovijedanoj priči nije potrebno više detalja o putovanju.

U Sentimentalnom putovanju dobivamo dobro formiran, sukladno zakonima pripovijedanja dobro izabran i uređen slijed događaja s relativno malo radnji i zbivanja. Pored brojnih književnih vrsti, koje se u njoj mogu naći, Fejtövu knjigu s pravom čitamo kao roman, i to kao književno djelo koje u skladu s romaneskom tradicijom integrira formalne oznake, načine govora i reprezentacijske postupke drugih pismenih i usmenih književnih vrsta. I sam Fejtö razmišlja o žanrovskoj pripadnosti Sentimentalnog putovanja, spominjući više književnih vrsta. Najprije ga u predgovoru iz 1988. spominje kao knjigu (što nije književna vrsta, nego publikacijski oblik), zatim ga suprotnom tvrdnjom veže uz autobiografiju, i konačno ga naziva člankom što je pak publikacijska forma novinskih vrsta: „Zapravo, ona prvotno nije ni nastajala u obliku knjige, jer u to doba još nisam ni imao dovoljno samopouzdanja da krenem u pisanje knjige, a bio sam i premlad za autobiografiju. Tekst sam pripremio kao prilog za Nyugat (Zapad). ${ }^{15}$ U odnosu na „sadržaj” zapravo govori o književnim vrstama: „... u kojoj se rapsodično miješaju uspomene iz djetinjstva, dalmatinske putopisne

\footnotetext{
${ }^{13}$ Fejtö, Sentimentalno putovnje, 241. (istaknuo autor)

${ }^{14}$ Fejtö, Sentimentalno putovnje, 242.

${ }^{15}$ Fejtö, Sentimentalno putovanje, 6.
} 


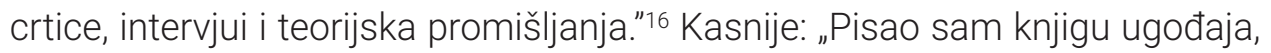
poetičnu a ne znanstvenu raspravu." ${ }^{17}$

I te umetnute vrste, koje funkcioniraju kako u pisanju tako i u čitanju, također su prethodne reprezentacije, između svijeta događaja i svijeta romana. Posreduju kulturne forme koje oblikuju identitet autobiografskog pripovjedača. Među tipovima romana, uz roman o putovanju, može se uzeti u obzir i roman o odrastanju: Sentimentalno putovanje je osvrt na okvire vlastitog odrastanja i to na onaj njegov dio koji je pripovjedač ranije potisnuo u pozadinu, te proširivanje svijeta mađarskog mladića na one njegove dijelove koji su odvojeni od tog svijeta iz djetinjstva i koji su skoro u potpunosti i odstranjeni, koji su ostali izvan granica svijeta koji je mogao smatrati svojim.

Preveli: Isabelle Kristović, Ružica Kovač, Dávid Karácsonyi, Ema Sabo, Martin Sukalić

(Rad je preveden u sklopu kolegija Književno prevođenje ak. god. 2018/19. Voditeljica: Kristina Katalinić)

\section{Literatura}

Fejtö, Ferenc. Sentimentalno putovanje. Zagreb: Durieux, Dubrovnik: Dubrovnik University Press, 2003.

Fejtő, Ferenc. „Zágrábi utinapló." Nyugat, 1935, 11. Pristup: 10. listopada 2018. http://epa.oszk.hu/00000/00022/00598/18907.htm

Jaspers, Karl. Uvod u filozofiju, Dvanaest radijskih predavanja, s njemačkog preveo Željko Pavić (Zagreb: Naklada Breza, 2012), 16.

Kovács, Árpád. Az irodalmi esemény. Budapest: Gondolat, 2013. [Universitas Pannonica Könyvek 22.]

Schmid, Wolf. Elemente der Narratologie: 3., erweiterte und überarbeitete Auflage. Berlin: De Gruyter, 2014.

\footnotetext{
16 Fejtö, Sentimentalno putovanje, 6.
}

17 Fejtö, Sentimentalno putovanje, 10. 


\section{Esemény és narráció Fejtő Ferenc Érzelmes utazásában}

Fejtő Ferenc könyvének címével Laurence Sterne Érzékeny utazására utalva arra a hiátusra is felhívja a figyelmet, amely az utazás eseményei, ténnyé tett körülményei, valamint ezek percepciója és elbeszélésmódja közt fennáll. Az esemény és az elbeszélés közti viszonyt érinti a Fejtő-mű múfajiságának problémája is. Mi és hogyan válik az utazás történéseiből elbeszélésre érdemes eseménnyé? Az elbeszélés közvetíti a tapasztalatot vagy létesíti a tapasztalatból nyelvileg megoszthatót? Hogyan kerül színre a cselekvők aktivitása, milyen identitás létesül a múben az elbeszélés által? Milyen utazási narratívát érvényesít Fejtő? Végső soron: hogyan írható körül az elbeszélésből megismerhető elbeszélőfőhős, és mi az utazásának/elbeszélésének a tétje? Az elemzésnél Jurij Lotman, Wolf Schmid, illetve Kovács Árpád eseményértelmezéseit érvényesítem, illetve a fogalomalkotásnak a kognitív metaforákban tetten érhető és az elbeszélésben érvényre jutó folyamatait vizsgálom.

Kulcsszavak: Fejtő Ferenc, esemény, narráció, önéletírás, fikció, reprezentációs eljárások 



\section{9 \\ LADÁNYI \\ István}

Veszprém

\section{Esemény és narráció Fejtő Ferenc Érzelmes utazásában}

—ejtő Ferenc, könyvének címével Laurence Sterne Érzelmes utazására — utalva arra a hiátusra is felhívja a figyelmet, amely az utazás történései, cselekvései, ezek percepciója, ténnyé tett körülményei, valamint mindezek elbeszélésmódja közt fennáll. Egy előzetes, ismert, tekintélyes müre hivatkozik a címmel, amivel reflektálttá teszi az utazás leírásának tevékenységét, utalva az utazások sokféleségére és az útleírások hagyományára. Az esemény és az elbeszélés közti viszonyt érinti a Fejtő-mű műfajiságának problémája is.

Ez a könyv a regénymüfaj 20. és 21. századi gyakorlatainak ismeretében problémátlanul olvasható regényként. Számos olyan mozzanata van, amely kimozdítja mind az önéletírás, mind az útleírás, mind az esszé keretei közül. Különös sajátossága azonban, hogy folyamatosan igényt tart a nem fikciós olvasatra, hogy bármennyire ismeretlen és ellenőrizhetetlen számunkra mindaz, amit elbeszél, az ellenőrizhető vonatkozások révén, a szöveg olvasási hagyományai ismeretében mégis a valóságról szóló igazságigényű beszédnek olvassuk. A szöveg világát megelőző valós eseményeket tételezünk, a szerző Fejtő Ferenc valódi utazását rendeljük hozzá, amely eseményekhez az elbeszélő sajátosan, de az igazmondás igényével viszonyul.

Az Érzelmes utazás egyedi alkotás az életmüben. A szintén önéletrajzi Budapesttől Párizsig inkább megfelel a hagyományos emlékiratnak, amelyben egy megélt élet részleteit és egészét próbálja meg együtt elbeszélni, az egész leélt életnek állít emléket, tulajdonít jelentőséget, a teljes saját élet összefüggéseire tekintettel. Az Érzelmes utazás egy - pontosabban kettő - élménycsoport 
elbeszélése. A magyar fiatalember számára a család zágrábi ágával töltött napok, valamint a horvát Adrián tett utazásának élménye szóra bíró eseményekké válnak. Az utazási regények mintájára olyan, utazásról szóló beszámolóvá, amely az átélő ént azáltal teszi elbeszélővé, hogy az úton szerzett élmények önmagával való szembenézésre késztetik, amelynek során az átélő én az átéltek tükrében vizsgálja önmagát, egyszerre önmagaként és önmaga idegenjeként.

Ismerős világba utazik egyrészt - gyermekkora színhelyére és a saját családja körébe -, de amely világ, az átélő én, vagyis a Zágrábba hosszú idő után visszautazó fiatalember felnőtté válása és az őt fogadó közeg változásai révén már eltávolodtak egymástól annyira, hogy a magától értetődőségen túl viszonyuljanak egymáshoz, folyamatos mérlegelésre, vizsgálatra, értelmezésre késztetve az átélő ént. Határhelyzettel indul a regény, és az átélt események végig fenntartják határesemény voltukat az elbeszélésben. Az első mondat a szó szoros értelmében vett határátlépést beszél el, de az elbeszélésben szimbolikusan is határátlépéssé válik. Az országok, a háború és határok története, valamint ebben a nagy történetben a család története próbára teszik az átélő én azonosságát, a találkozások a családi háló újraszövésére késztetik, a kötődések, viszonyok értelmezésére kényszerítik, a zágrábi utazás az anyai örökséggel való szembesülés útja lesz, az elbeszélés pedig a saját élet ilyenként való elfogadását, az elbeszélés által történő elsajátítását jelenti. Aktivizálhatjuk ezek kapcsán Karl Jaspers határhelyzet-fogalmát: „....ezek a szituációk azok, amelyekből nem lábalhatunk ki, amelyeken nem változtathatunk. A csodálkozás és a kételkedés: ezeknek a határhelyzeteknek a felismerése."1

Másrészt Zágráb után egy teljesen másik világba utazik, a zágrábi napok otthonos idegenségére épülve a tenger, a tengerparti életmód és a korabeli, már működő turizmus, a más utazókkal való találkozások az egyedül utazó fiatalembert folyamatosan reflexióra és önreflexióra késztetik. Itt is hangsúIyosan megfogalmazódik a határ átlépése: a tenger megpillantása Fejtőnél is, mint annyi más kontinentális utazónál jelentőségteljes határesemény lesz az elbeszélésben szembeállítva az erre nem fogékony, érzéketlenül utazókkal, akik ugyanazt a történést nem élik meg eseményként.

Wolf Schmid az Elemente der Narratologie című munkájában az eseményt állapotváltozásként határozza meg, ami „sajátos feltételek” között megy végbe, és kap jelentőséget². Jurij Lotman valamilyen előzetesen létező szabályok áthágásával, például „valamilyen tilalom megszegésével” hozza kapcsolatba a fogalmat ${ }^{3}$. Lotman egyik magyar értelmezője, Kovács Árpád az esemény

\footnotetext{
1 Karl Jaspers, Bevezetés a filozófiába (Budapest: Európa, 1989), 20.

2 Wolf Schmid, Elemente der Narratologie: 3., erweiterte und überarbeitete Auflage (Berlin: De Gruyter, 2014), 14-15.

3 Idézi Schmid, Elemente der Narratologie, 13.
} 
fogalmát körüljárva fontos megkülönböztetésnek tartja az esemény különválasztását a közvetlen megtapasztalás világától: „A köznapi szemlélet az eseményt az állapottal, a folyamattal, a változással és az átalakulással összevetve érzékeli. Tudnunk kell azonban, hogy ez a szemlélet nem a közvetlen tapasztalatot önti formába. Előzetes értésünk hiedelmeken, reprezentációkon, szimbolikus közvetítéseken alapul." ${ }^{4}$ A cselekvések és történések világában az eseményszerüség megképződéséhez már eleve hozzá tartozik az értelemadó összefüggésekbe helyezés, jelentés- és jelentőségtulajdonítás. Egy cselekvés, történés önmagán túlmutató jelentőséget kap. „Az elbeszéléselméletek többsége szerint eseménynek általában az tekinthető, ami a narratív közvetítés következtében egy történet alkotórészévé válik: az elbeszélés az eseményt egy történetbe integrálja." 5

A saját élet interpretációiban, a cselekvések világában folyamatosan mondott öninterpretációiban vagy az önelbeszélések különböző müfajú, szóbeli vagy írásbeli változataiban egy-egy cselekvés, történés tehát kiemelkedik a cselekvések, történések végtelen sorából, esemény státusra tesz szert, a neki tulajdonított/benne felismert jelentésekkel az értési, önértési folyamat részévé válik.

Az esemény tehát nem mindaz, ami megtörténik, hanem az, ami a cselekvések és történések világából jelentésekkel telítetten körvonalazódik az azokat átélő és önmagára vonatkoztató én számára. Maga is létrehozott, kognitív konstrukció. Kell hozzá az azokat átélő én figyelme, kiválasztó és értelemadó tevékenysége. Érvényesülnek benne mindazok az előzetesen létesült kulturális alakzatok, amelyeket az átélő én hordoz, az előzetes megformálások, amelyeket az átélő én érvényesít a cselekvésben, a többi résztvevő cselekvéseinek koreográfiája és értelmező tevékenysége.

Fejtő Sterne művére, az Érzelmes utazásra tett utaláson túl számos alkalommal nyilvánvaló jelét adja az elbeszélés irodalmi megformáltságának, az irodalmi előképek meglétének, az elbeszélés tapasztaltakat közvetítő s ugyanakkor az elbeszélés által formáló voltának.

Fejtő az elbeszélői hang mellett, sajátos polifóniában következetesen szóhoz juttatja az elbeszélés által színre vitt szereplőket, azokat, akik révén az átélő én szembesül a család általi meghatározottságaival, akiknek beszédeseményei (és cselekvései is) alakítják az önmagát szemlélő átélő ént, az elbeszélésben pedig az abban létesülő elbeszélő ént.

Az önelbeszélő számos alkalommal átadja a szót valamelyik hősének, vagy függő beszédben közvetíti a hősök szólamát, sőt ennek a fordítottjával is eljátszik: az önmagát figyelő elbeszélő harmadik személyben kezd beszélni magáról, reflektálttá téve az elbeszélés megformáltságát.

4 Kovács Árpád, Az irodalmi esemény (Budapest: Gondolat, 2013), 11. [Universitas Pannonica Könyvek 22]

5 Kovács, Az irodalmi esemény, 14. 
Az elsőre jellemző példa a nővére, Nada megszólaltatása első személyben. A naplószerű szerkezetben július másodikára rögzített elbeszélésben a körülményeket fölvázoló, rövid bekezdésnyi bevezetés után („Náda az ágyon pihen, figyeli magában a magzat fészkelődését s találgatja, hogy fiú lesz-e vagy lány?"), vagyis a jövőre vonatkozó jelzés után a nővér a maga történetét kezdi mondani, a naplóiró tevékenységére utalva, instrukciókat adva és interpretációt kínálva, hogy hogyan írja meg őt a naplójában. ${ }^{6}$

"- Szeretném tudni, hogy mit jegyzel mindig és miért nem mutatod meg? Bizonyára te is memoárjaidat írod, mint az írók mostanában szokták. De velem még nem is beszélgettél, mióta nagy fiú lettél, s nem is tudom, mit írhatnál rólam? Pedig bántana, ha nem lennék benne a memoárjaidban. De azt kikötöm, hogy ha megemlítesz, ne mostani nyárspolgári mivoltomban írj meg, hanem egy kicsit idealizálva. Én most egy nagy hasú filiszternő vagyok, aki a gyerekem ruhácskáit varrogatom s kinek a háztartáson kívül nincsen is egyéb gondom. Könyveket sem igen érek rá olvasni és egészen elmaradtam a világtól, lassan már magyarul is elfelejtek, s a magasabb problémák iránt is elvesztem az érzékemet."7 A nővér tehát „bekéri” magát a történetbe, s előzetesen megformált képét kínálja fel, közlekedve a voltaképpen a múltból örökölt vágyott önképe és a között a kép között, amilyennek magát aktuálisan látja. Mindezt a maga történetének összefoglalása követi hosszú oldalakon keresztül. A fejezet végén feltűnő Fejtő szerzői döntése, hogy elbeszélője nem veszi vissza a szót, nem foglalja tehát keretbe a nővér elbeszélését, ugyanakkor az így átadott szó gesztusával jelzi, hogy elbeszélője nem veszi át Nada önképét, nem is interpretálja saját képpé, hanem meghagyja elbeszélésében idegen, a saját szólammal dialogizáló szólamként.

Ehhez hasonlóan, különféle elbeszélésváltozatokban, a rokonok végiglátogatásának narratív szerkezetében rajzolja meg a családi arcképcsarnokot időről időre az elbeszélt személyhez igazított elbeszélői eszközzel utalva az interpretációk feltételességére, beleértve ebbe a hősök önértelmezését és az elbeszélői értelmezést is. Irónia és önirónia, tudatosított rövid beszédműfajok vagy az elbeszélői bekeretezés egyéb eszközei teszik láthatóvá az elbeszélői aktivitást.

Fejtő elbeszélője végig irodalomtudatos, felismeri, rögzíti és értelmezi nemcsak önmaga írói tevékenységét, hanem az események világában is a színjátékot, az aktívan létrehozott koreográfiákat, a minták szerint végig vitt eseménysorokat. Ottó bácsi figurája (aki az első publikációban, Zágrábi utinaplóban még Józsi bácsiként szerepel) ${ }^{8}$ mintegy a gyorsan mozgó képkoc-

6 Fejtő Ferenc, Érzelmes utazás (Budapest: Magvető, 1989), 51.

7 Fejtő, Érzelmes utazás, 51-52.

8 Lásd: Fejtő Ferenc, „Zágrábi utinapló”, Nyugat, 1935, 11. Letöltve: 2018. október 10. http:// epa.oszk.hu/00000/00022/00598/18907.htm 
kákkal dolgozó régi filmeknek már a technikából következően kissé komikus alakjaként kerül elénk a samobori kirándulás kötelező elemekből épülő, szabályszerűen végigjátszott koreográfiájával. Erika Druzovics színésznő árnyaltan felépített nagyjelenetet játszik a müben, és ebben az esetben nemcsak a szereplő színrevitelében, hanem önmaga elbeszélői egyszerűsítése felett is érvényesíti Fejtő az iróniát.

„A szoba csupa szerep, csupa nyugtalanság, csupa dráma lett tőle. Sebesen beszélt, hol erre, hol arra - úgy dobálta háromfelé a szerepeit, mint a búvész a három tányérát magasba; csöpp szünetet se tartott, szinte három hangon beszélt egyszerre, crescendókkal és accelerandókkal, csodálatosan. Három síkban élt egyszerre, valahogy úgy, hogy Tóni néninek szólt valamit, ugyanakkor Ottó bácsi tányérjából evett és az én szemembe nézett, vagy fordítva: Ottó bácsira mosolygott pajzánul, Tóni néni kezét simogatta és tőlem kérdezte mély részvéttel: Ó, ön író? Talán regényt is írt? Akkor írja meg az én regényemet is. Jó?" 9 Az egész zágrábi út mögött ott álló, már rég halott anya alakja pedig azok révén a kéziratok révén rajzolódik meg, amelyeket Ottó bácsi nyújt át az immár felnőtt fiúnak: az anya írt és kapott levelei és egyéb dokumentumai révén. Az anya által egykor kézben tartott és a keze írásával teleírt papírlapokat fogja most a kezében a fiú, tapintja őket, olvassa a kézírást, és írja, amit olvas ezeken a papírokon. Ezt a közvetlen megtapasztalást előkészíti a könyv szerkezetében az ezt majdnem közvetlenül megelőző, jelentéstartalmában ellentétes előjelű fejezet: a rövid - és az elbeszélésben is nagyon rövidre fogott - látogatás az anya sírjánál, ahol nem történik meg a találkozás az anyával, az elbeszélő az ürességet, az anya távolmaradását rögzíti.

A fiú az egész éjszakát a levelek olvasásával tölti, amelyek részletgazdagon megidézik az anyát és az egykor volt életet.

„Mennyi új vonás az arcon, amelyre csak halványan, mintegy fénykép után emlékszem! Szinte érzem a leheletét a papír fölött, amelyre szép betǔit rajzolja! Látom a szeme csillogását este, kihajolva a fiumei lakás ablakán, a színesen s lármásan nyüzsgő utca fölé, látom sétálni a kormányzósági park pálmái között, sárgás csontlegyezőjével legyezve arcát s kergetve a szúnyogokat magától, míg a pavilonból a zene szól! (...) Ó, látom anyámat, mint a temetőben szerettem volna látni, ahogy szomorúan és kedvesen, halottan és elevenen néz rám, valami térből, amely nem kívül van, hanem belül, néz rám, ahogy aranyozott rámából néznek néha s alig észrevehetően megmozdulnak a képek." ${ }^{\prime 10} \mathrm{~A}$ másnapot is a levelek olvasásával tölti, a regény naplószerkezetében ez a nap is teljes egészében az anya alakjának szentelődik, a levelek részleteit mesélve és interpretálva. Helyenként jelzi az élete eseményeit közvetító és értelmező levélíró anya elfogultságait, továbbá beleszövi a családi értelmezé-

\footnotetext{
9 Fejtő, Érzelmes utazás, 69.
}

${ }^{10}$ Fejtő, Érzelmes utazás, 105. 
si hálót is, néven nevezve a pletykák készen kapott, értelemadó szövedékét, aztán Dóra néni hangján Kareninnek nevezve az anya első férjét, jelzi, hogy a személyek és a történések értelmezésébe mennyire beleszóltak az olvasott regények, a kész életértelmezési minták, a szereplők mintegy belekényszerítik egymást és magukat az önértelmezésekben, de talán a cselekvéseikben is a múvekből ismert szerepkörökbe. Az anya alakja révén megidézett Fiume pedig a könyv második, adriai részét is fölvezeti már. Az anyáról szóló fejezetsor végére teszi Fejtő Fiume dicséretét, a városdicséret műfajának megfelelő vocativusban. „Dicsértessél tehát te is, Fiume, dallamos, lágy neveddel, mely kellemes, mint a Fiumara patak csörgedezése a határodon! Dicsértessél Quarneród kék vizével és ég és víz között lebegő fehér vitorláiddal!"11 Ez a dicséret a Zágrábot megszólító dicséret párja, erre utal a mondat eleji „tehát”: „Dicsértessél tehát te is, Fiume... Zágráb dicsérete közvetlenül a városba történő megérkezés után kerül sorra, amikor az utazó először sétál ki a városba, ellátogatva a nővérével a piacra. A regény tudatos megformáltságát (szemben az utazás naplószerű, spontán rögzítésével) jelzi ez az egymástól távol elhelyezett két vocativus is, hiszen Zágrábot is megszólítva dicséri és vallja sajátjának: „Szülővárosom vagy, Zágráb, pedig nem benned születtem, mégis a te öledben érzem magam csak egészen otthon."12 A városdicséret müfajának megfelelően itt is sorolja a város ékességeit, a műfajtól eltérően pedig az azonosulás mellett jelzi a személyes távolságtartást is.

De Fiume előtt még ott van a zágrábi rész végén a találkozás Krležával, továbbá az unokaöccsének, Náda kisfiának a megszületése. Az unokaöccs születése zárja a zágrábi eseménysort, megnyitva a családtörténetet a jövő felé.

A fiumei vonatúttal kezdődő tengerparti, illetve tengeri utazás az útleírások hagyományos narratíváját követi, a helyek bejárását, az útitársakkal történt találkozások leírását. Az adriai út megidézésében is azonosíthatunk egy markáns elbeszélői váltást, amelyet a Zágrábot és Fiumét invokáló városdicséretek mellé állíthatunk. A tengeri út végén az önmagát folyton megfigyelő, az eseményeket írásban rögzítő elbeszélő egy voltaképpen ironikus gesztussal félrevonja a leplet erről az önmegfigyelői és elbeszélői pozícióról, és első személyből második, majd harmadik személyre vált. A váltás az irodalmi hagyomány, az írói szerepkör kontextualizálása keretében történik.

„Délelőtt hosszas kereséssel sikerült megtalálnom Hella nevét egy penzió vendégkönyvében. A vezetéknevét elfelejtettem s csak most jut eszembe: Csehova. Csehov Sirályára kell gondolnom, arra a fásult szenvedélyre, amelylyel a csehovi Író szemében az élet minden mozzanata, a lélek intim rezdülése »témává«, betúvé, jegyzetté válik. Itt ülök és jegyzek most én is, különös idegenségben magamtól. (...) Emlékszem, milyen különös volt a ráébredés erre

\footnotetext{
${ }^{11}$ Fejtő, Érzelmes utazás, 137.

12 Fejtő, Érzelmes utazás, 28.
} 
a hatodik érzékszervre még kamaszkoromban, mennyire megzavart, megtréfált, megundorított, hogy magamban, bármit gondolok és cselekszem, akár fáj, akár örülök, az a »hatodik érzékszerv« mindent észrevesz és feljegyez, mindenből mondatokat igyekszik gyártani, egykedvűen, részvét nélkül, ironikusan. A legfelháborítóbb ennek az állapotnak a gépszerűsége. Szerelmet érzel s tüstént hallod magadban a borzasztó motyogást: »sze-rel-met érez«, mintegy harmadik vagy ötödik személyben. »A haja ilyen, a nyaka olyan stb. « Valami nincs rendben! »Úgy érzi, hm, hogy valami nincs rendben«, s a legbosszantóbb, hogy előveszed a ceruzádat s leírod, amit az illető diktál."13 Itt már második személyben beszél az elbeszélő, szólítja meg az írói ént, és a „harmadik vagy ötödik személy" az, aki diktál. A saját élet szövetének figyelése pedig olyanná válik, mint egy regény olvasása. "Szinte fölösleges az első személy” - mondja Fejtő elbeszélője: „Lejegyzed: Hellát nem találta odahaza, mert a bárkán halászni rándult, s bizonytalan mikor jön haza." ${ }^{4}$ És hosszan lehetne idézni az írói tevékenységnek ezt az önreflexív beágyazását az elbeszélésbe, amely magának ennek az önreflexiónak a megjelenítésével és kommentálásával zárul. Ez a szövegrész a könyv hangsúlyos helyén, a legvégén helyezkedik el, kommentálva az elbeszélő egész tevékenységét. Ezután már csak a visszaút megkezdésének eseménye szerepel, a felszállás a Splitből Zágráb felé tartó vonatra. Itt elhallgat az elbeszélő, Zágrábtól elbúcsúzott már a fiumei vonatút előtt, az elbeszélt történetnek nincs szüksége az utazás további részleteire.

Viszonylag kevés cselekvés és történés jól megformált, az elbeszélés igényeinek megfelelően kiválasztott és elrendezett eseménysorát kapjuk az Érzelmes utazásban. A számos müfaj mellett, amelyekből részesül, joggal olvassuk regénynek Fejtő könyvét, mégpedig a regény múfaji hagyományainak megfelelően más írásbeli és szóbeli múfajok formai jegyeit, beszédmódjait, reprezentációs eljárásait integráló írásműnek. Fejtő számára is elgondolkodtató az Érzelmes utazás müfajisága, több müfajt is szóba hoz. Először könyvként hozza szóba 1988-as előszavában (ami nem múfaj, hanem publikációs forma), aztán egy tagadó, vagyis a lehetőséget visszavonó álítással az önéletíráshoz köti, végül cikként nevezi meg, ami az újságmúfajok felett álló publikációs forma: „Tulajdonképpen nem is könyvnek indult, ahhoz még nem volt akkor elég önbizalmam, hogy könyvbe kezdjek, és túl fiatal is, hogy önéletrajzot írjak. Cikknek készült, a Nyugat számára." ${ }^{15}$ A „tartalomra” vonatkozóan pedig voltaképpen müfajokat hoz szóba: „....amelyben gyermekkori emlékek, dalmáciai útleírás, interjúk és teoretikus elmélkedések kavarognak rapszodikusan."16 Később: „Hangulatkönyvet írtam, lírát, és nem tudományos értekezést."17

\footnotetext{
${ }^{13}$ Fejtő, Érzelmes utazás, 245-246. (Kiemelés tőlem, L. I.)

14 Fejtő, Érzelmes utazás, 247.

${ }^{15}$ Fejtő, Érzelmes utazás, 8.

${ }^{16}$ Fejtő, Érzelmes utazás, 8.

17 Fejtő, Érzelmes utazás, 12.
} 
Ezek a beemelt, az írásban és az olvasásban is müködő müfajok is előzetes reprezentációk az események világa és a regény világa között. Közvetítik azokat a kulturális formákat, amelyek az önéletrajzi elbeszélő azonosságát alakítják. A regénytípusok közül az utazási regény mellett a nevelődési regény hozható szóba, az Érzelmes utazás visszatekintés a saját nevelődés kereteinek arra a részére, amelyet az elbeszélő korábban háttérbe szorított, a magyar ifjú világának a kitágítása a tőle gyerekkorában elzárt és jóformán idegenné tett, a sajátnak tudott világ határain túlivá lett, nagyvilági részeire.

\section{Irodalom}

Fejtő Ferenc. „Zágrábi utinapló.” Nyugat, 1935, 11. Letöltve: 2018. október 10. http://epa.oszk.hu/00000/00022/00598/18907.htm

Fejtő Ferenc. Érzelmes utazás. Budapest: Magvető, 1989.

Jaspers, Karl. Bevezetés a filozófiába. Budapest: Európa, 1989.

Kovács Árpád. Az irodalmi esemény. Budapest: Gondolat, 2013. [Universitas Pannonica Könyvek 22.]

Schmid, Wolf. Elemente der Narratologie: 3., erweiterte und überarbeitete Auflage. Berlin: De Gruyter, 2014. 


\section{Događaj i naracija u Sentimentalnom putovanju Ferenca Fejtöa}

Aludirajući naslovom svoje knjige na Sentimentalno putovanje Laurence Sternea, Ferenc Fejtö skreće pažnju na hijat koji stoji između putovanja kao događaja, okolnosti u kojima se ono odvija te njihove percepcije i načina na koji su ispripovijedane. Odnosa između događaja i pripovijedanja dotiče se i problem žanrovske određenosti Fejtövog djela. Što se i kako iz putovanja kao zbivanja pretvara u događaj vrijedan propovijedanja? Posreduje li pripovijedanje iskustvo ili iz iskustva stvara ono što je moguće prenijeti jezikom? Kako je prikazano djelovanje aktera, kako u djelu kroz pripovijedanje nastaje identitet? Kakve narative putovanja ostvaruje Fejtö? I u konačnici: kako se može okarakterizirati pripovijedač-glavni junak kojeg upoznajemo kroz pripovijedanje, te što je ulog putovanja/pripovijedanja? $\mathrm{U}$ analizi će se primijeniti interpretacija događaja prema Juriju Lotmanu, Wolfu Schmidu, kao i Árpádu Kovácsu, odnosno ispitat će se procesi stvaranja pojmova koji se mogu vidjeti u kognitivnoj metafori, a potvrđuju u pripovijedanju.

Ključne riječi: Ferenc Fejtö, događaj, naracija, autobiografija, fikcija, reprezentacijski postupci 